\title{
Correction to: Flow process development and optimization of halo-amine coupling through customized flow processing equipment using DoE approach
}

\author{
Girish Basavaraju $^{1,2} \cdot$ Sharon D'Souza Lydia ${ }^{1}$ Ravishankar Rajanna ${ }^{2}$ \\ Published online: 6 October 2020 \\ (C) Akadémiai Kiadó 2020
}

\section{Correction to: J Flow Chem}

https://doi.org/10.1007/s41981-020-00099-1

This erratum is published as author affiliation was overlooked during proofing Dayanand Sagar College of Engineering needs to be correctly read as:

Dayananda Sagar College of Engineering.

Original article has been updated thus.

Publisher's note Springer Nature remains neutral with regard to jurisdictional claims in published maps and institutional affiliations.

The online version of the original article can be found at https://doi.org/ 10.1007/s41981-020-00099-1

\footnotetext{
Girish Basavaraju

girish.basavaraju@gmail.com

$\triangle$ Ravishankar Rajanna

ravishankar70@gmail.com

1 Syngene International Ltd, Bengaluru, India

2 Dayananda Sagar College of Engineering, Bengaluru, India
} 